\title{
Three Means of Indian Ocean Trade: Bartering, Purchasing, and Gifting
}

\author{
Langyue $\mathrm{Hu}^{*}$ \\ Shanghai Yue Kong Pao Senior Secondary School, Shanghai, 200042, China,
hulangyue@126.com

\begin{abstract}
This paper mainly explores three means of Indian Ocean trade: bartering, purchasing, and gifting, which happened around the middle of the first century CE. Through analyzing the general patterns of imports and exports and case studies of specific markets, possible causes and their impacts on the local economies will be presented. In conclusion, three methods of trade, combined with the efforts from each trader, resident, and society fueled a dynamic and unique trading network on the Indian Ocean. This work gives the reader a holistic understanding and avoids a reductionist approach that generalizes the trading method and denies the variations.
\end{abstract}

Keywords: Indian Ocean Trade, Silk Road, Periplus

\section{INTRODUCTION}

Periplus Maris Erythraei, completed by a Greekspeaking Egyptian merchant around the middle of the first century CE, provides a detailed account of two maritime lines of trade around the Erythraean Sea, both of which started from the Egyptian port of Myos Hormos. As shown in Figure One: the first one followed the coast of Africa, while the second went eastward as far as India. Periplus not only demonstrate to the readers how trades were taking place, it also showcases the seasonal departure and arrival times (as shown in Figure Two), the use of monsoon wind, the possibility of specialized production, and the effect of trade on stage formation. However, this paper will mainly zoom in on three means of obtaining goods: bartering, purchasing, and gifting that took place during the Indian Ocean Trade. The Roman merchants employed these three methods interchangeably to maximize profit. This paper provides a detailed explanation of three means of trade, the possible causes, and their impact on the local economies. The method will mainly be analyzing the general patterns of imports and exports and case studies of specific markets. Periplus Maris Erythraei has some limits because it's only from a single viewpoint, consequently some goods might be excluded from Periplus's narrative. Also, the geographical, economical, and political background are not explained thoroughly because presumably Periplus only stayed in different ports for a relatively short period.

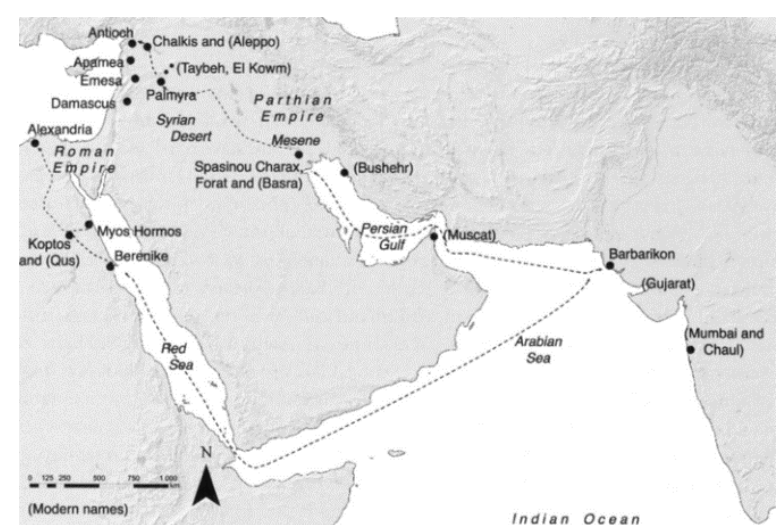

Figure 1: the reconstruction of ancient routes in the Persian Gulf [1]

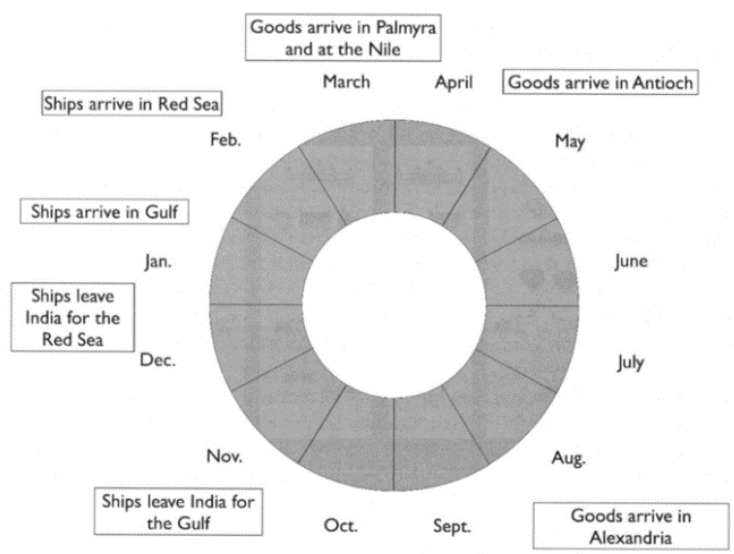

Figure 2: seasonal departure and arrival times for commodities [1] 


\subsection{Bartering}

Comparing to purchasing and gifting, bartering was a more common way of payment during the maritime trade in the first century CE. In the African and Arabia trade routes, from Myos Hormos to the continent of Azania, yielded tortoise shell, frankincense, cassia, and ivory. Comparatively, the most diverse goods were provided by India, including textiles, pearls, silk, tortoise shell, spices, aromatics, and gems. And Egypt Roman merchants obtained those goods by providing the native communities with cloth, drinking vessels, metals, and food.

The reasons behind the success of bartering lay firstly in the careful trading strategies of the Roman traders. For example, from Myos Hormos to Adulis, commodities like "undressed cloth made in Egypt for the Berbers" and "gold and silver plate made after the fashion of the country" were imported in exchange for "ivory", "tortoiseshell", and "rhinoceros-horn", etc [2]. It is worth noticing that Periplus included detailed descriptions of the consumers for specific goods imported to the local communities. For instance, the iron imported was for the weapons which they used to fight against wild beasts and enemies, which corresponds to the reference earlier about the attacks from the "barbarous natives" [2]. Details like "made in Egypt for the Berbers" [2] showcases the possibility of a mature net of communication that ensured supply could efficiently meet the demand and maximize the profit. If the local consumers received what they want, the chance of Roman Egypt merchants receiving goods that are very valuable to them would also increase. These two examples demonstrate that a detailed level of understanding merchants had about different markets helped to ensure double coincidence of wants during the process of bartering.

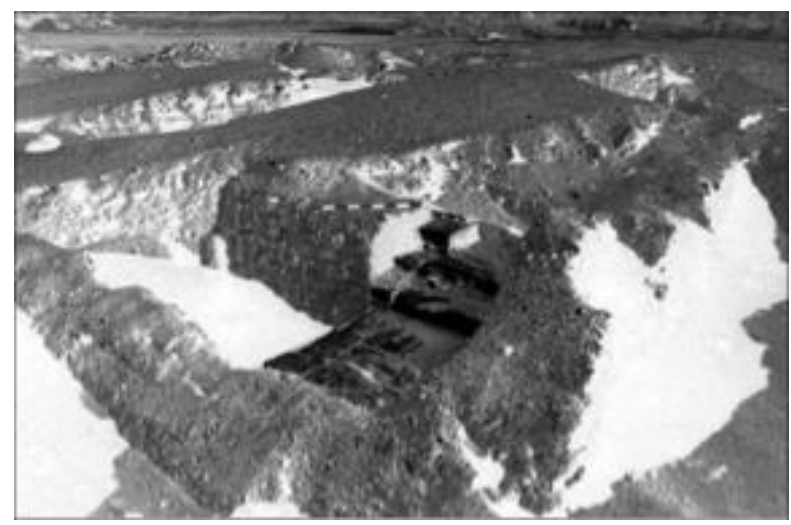

Figure 3: Myos Hormos, view of structure looking south-west $($ Scale $=1 \mathrm{~m})$. Photo by S.E. Sidebotham [4]

Another evidence that shows the merchants had taken careful consideration was the amount of glassware they carried. "Flint glass", "crude glass", and "vessels of glass" were imported to ports like Barbaricum, Muza, and Avalites [2]. Glasses were risky to transport because with a little damage the merchants won't be able to sell them. Therefore, it proves that the traders were very certain about the level of popularity these commodities received and knew it was worth the effort.

Except for glassware, bringing heavy goods that would take up large spaces also proves that the merchants have thought carefully about what to bring. Unlike spices, metal has a high storage factor and does not utilize the space most efficiently, unless the merchants were sure about the high profit, they would not bring them.

Despite the planning from Roman merchants, how nicely the supply and export in the ports along the African and Indian coast matched the demand of Roman merchants also explains why bartering took place. For example, aromatic and spice were very important to the Roman Empire because they could be used in various medicinal, funerary, religious, and culinary context [3]. In addition, from the merchant's point of view, aromatic and spice utilize the space on the boat in the most efficient way which made more money comparing to bulks of larger commodities. The tax rate at that time was twenty-five percent, and one voyage around the Indian Ocean involved great expense. Therefore, the merchant must maximize their profit with the help of bartering. Coincidentally, India produced no lead and copper according to Pliny [3]. Therefore, metals which are nonprecious to the Roman merchants could be important to the residents along the Indian coast. The Roman merchants were very aware of that so they bartered copper, tin, and lead for aromatics which, as mentioned above, brought them huge profit.

In conclusion, bartering could benefit both parties if conduct fairly and carefully when there is a double coincidence. But it did not always work, in some special conditions, the merchants purchase or send gifts to ensure the trade continued smoothly.

\subsection{Purchase}

Comparing to bartering, there was much less reference to purchase in Periplus Maris Erythraei. Most of the ports received only a small number of coins, and only one took in a large amount of them.

In Malao, there are iron and silver coins being imported, but not much. From the market of Myos Hormos to Adulis there was "a little coin for those coming to the market". [2] There might be two reasons behind the purchase being conducted. Firstly, there were probably local Roman traders who emigrated there due to the Indian Ocean trade. Although it was not directly mentioned in the descriptions of Malao and Adulis, elsewhere in the text, there was an example of "a mixture of Arabs and Indians and Greeks, who have emigrated to carry on trade" [2] in an island called Dioscorida, which hints at the possibility of emigration. Secondly, the locals 
might require some coins from the Roman traders arriving so that they can pay the Indian and Arabic traders. For instance, the port of Muza "carry on a trade with the far-side coast and with Barygaza, sending their own ships there" [2], and Barygaza regularly sent large vessels "loaded with copper and sandalwood and timbers of teakwood and logs of blackwood and ebony" [2] to ports like Ommana. These pieces of information imply that despite boats sent out by the Roman traders, the trade between each port conducted by the native residents also took place from time to time. Since those traders might not be interested in the local products like myrrh and frankincense in Malao, because they already produce enough of that themselves, and want the natives to pay in coins.

The port called Muziris along the Malabar Coast was there only place where "a large amount of coin" [2] is mentioned in the Periplus Maris Erythraei. The coins were used for two possible reasons. Firstly, there are several clear indications that there could be a local Roman colony. The Tabula Peutingeriana mentions that a Muziris had a temple dedicated to Augustus and there is evidence of the Roman settlement in Muziris [4]. And the Periplus Maris Erythraei speaks of the wheat that was imported that's "enough for the sailors, for this is not dealt in by the merchants there" [2]. The sailors could indicate the local Roman residents who arrived due to the Indian Ocean trade. The diaspora groups could provide the infrastructure of trust needed for people operating far away from home [5]. They were accustomed to the wheat miles away in their hometowns, therefore, unlike the native residents, they seldom eat local rice.

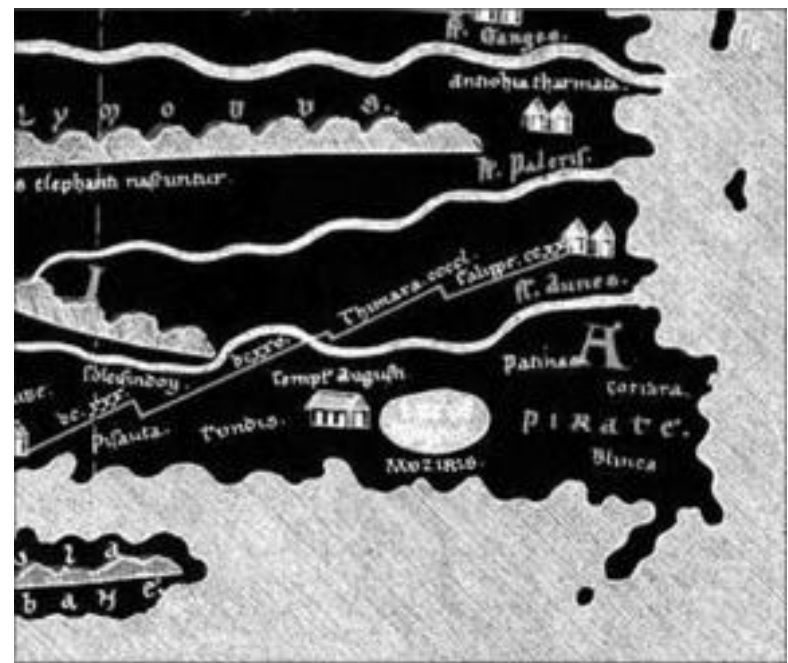

Figure 4: Tyndis, Muziris, Blinca and Comara on the map of Tabula Peutingeriana. [4]

In addition, the usage of coins could be caused by another reason. The export in Muziris includes fine pearls, ivory, silk cloth, transparent stones of all kinds, and diamonds which outpriced the imports of merely uncomplicated clothing and metal. Consequently, the
Muziris traders would also demand coins in addition to the imported commodities to make the transaction fairer.

Another commercial center that also lies on the Malabar Coast is called Barygaza. Although coins were also imported, they are not used for purchasing but to gain "a profit when exchanged for the money of the country" [2]. This is because the trades in Barygaza were controlled more by the King and the local community, which is indicated through the comparison of import and export between Muziris and Barygaza. At Barygaza, there were a lot of luxuries like "very costly vessels of silver", "singing boys", "singing boys", "beautiful maidens for the harem", and "fine wines" [2]. Comparatively, Muziris, belonging to the Kingdom of Cerobothra, was also ruled by a king, and it was even a port of leading importance. However, the import was less sophisticated comparing to Barygaza, mainly normal clothing, food, metals and there was no specific gift given to the king. Presumably, the kings lived the same lifestyle as the subjects. And the value of goods was lesser in Muziris and there was no indication of varieties of goods. Barygaza took in "thin clothing and inferior sorts of all kinds" [2], whereas Muziris only took in "thin clothing, not much" [2], probably undecorated. Barygaza took in at least some perfumes or plant products like storax and sweet clover, but in Barygaza there was none of that. This hints at the lower power the Muziris king had over the trade, he might not be able to make sure the import was of roughly the same value as export while bartering took place. The trade was mainly controlled by the Roman trades and there was even circulation of Roman currency alongside the kingdom's own monetary system. However, in Barygaza, one theory proposes that the king had a monopoly on the goods imported and the Roman coin did not enter the market of Barygaza, instead, there were collected and melted down to make their own coins at the same weight. This can generate them a lot of profit.

In conclusion, coins can be useful when the local residents whether from Roman or not, recognize them and find them useful. It could also be a tool to balance the value of import with the export. However, depending on the influence of the local authority, how people use the coins can vary across very similar trading centers.

\subsection{Gifting}

During the Indian Ocean, gifts were often given to the kings or the native residents. In the very last market town Rhapta of the continent of Azania, "a little wine, and wheat" are given "not for trade, but to serve for getting the goodwill of the savages" [2]. And there were also various references about commodities "to/for the kings" which implies that no payment was required. Kings were usually given horses, vessels of gold and polished silver, wrought gold and silver plate, wines, and etc. And there was even a reference of local rulers sending gifts back to 
the Roman Empire. Charibael, who lived in Saphar, is the lawful king of two tribes who maintained a good relationship with the Roman Emperors "through continual embassies and gifts" [2].

Gifts usually functioned as a form of tax. In most cases, the Roman monetary system did not apply to the local one, thus gifts instead of coins were used. Additionally, gifts also served as a way to enhance the bond between the Roman Empire and different ports. A lot of gifts improved the local residents' dependency on the merchants. For example, The Periplus reveals the demand for wine that existed in several East African, southern Arabian, and Indian ports. A lot of Greek and Roman sources state the level of popularity they received especially in India. Indian literature also highlights an appreciation toward wines by using them as very important plot devices in the play Charition. According to various descriptions, wine was probably a symbol for statue and delicacy [3]. In Barygaza the quality of the wine was described using "fine", which hints that the wine is being selected specifically for the kings. The cherishment or requirement of a specific kind of wine is probably due to the long-time connection with the Roman Empire that results in some form of acculturation. After all, according to Periplus Maris Erythraei, "in these places there remain even to the present time signs of the expedition of Alexander, such as ancient shrines, walls of forts and great wells" [2]. This connection is reemphasized by the provision of wine that couldn't be obtained elsewhere. To continue receiving this symbol of power, the king would probably offer protection or remove some restrictions to make the trade more efficient. The same case could also apply to ports like Rhapta that were controlled by native tribes.

The gifts were necessary because of the potential danger and restrictions encountered along the road. For instance, next to the port of Barygaza, it was very hard to enter or depart if the sailors were inexperienced, because "the rush of waters at the incoming tide is irresistible, and the anchors cannot hold against it" [2]. Despite the difficulties in sailing conditions, the restrictions can be very strict. For example, in the harbor of Moscha, goods were not allowed to be loaded on the vessel "openly nor by stealth" without the king's permission. If the Roman traders were on better terms with the rulers, the possibility of receiving help from local guides or having a loosened restriction would increase. The negotiation before barter or purchase could be simpler.

In conclusion, gifting could be an effective way to aid barter and purchase. As long as the goods were given were precious to the local communities so that they were more dependent on the Roman traders.

\section{CONCLUSION}

To sum up, the Roman merchants employed methods of bartering, purchasing, and gifting interchangeably in order to maximize the profit. Meanwhile, the influx of commodities and coins can impact the culture, style of living, and the monetary system in different local communities. Case studies are effect ways to investigate these three means of trade, however, since the merchants at that time did not need a very comprehensive understanding of the local society, most of the information is import and exported related. Thus, more in depth case studies should use other primary and sources to do some comparative studies.

It is challenging to do research on a period that is not well documented and have limited primary sources. Although my main investigating method is zooming in on specific cases in my primary source, I still need some secondary sources to support my arguments. I found some sources that are related but not exactly focused on my topic. This can count towards a limitation of my study since I had limited chances to engage in others interpretation toward Periplus Maris Erythraei.

However, this study overall is of significance because it draws attention on how Indian Ocean Trade and Silk Road have been over-simplified and over-idealized. In reality, each port was affected differently by the imports and exports. In addition, the trades did not always go smoothly: the traders don't always trade in the same way, careful considerations were required. The efforts from each trader, resident, and society together fueled a dynamic and unique trading network on the Indian Ocean.

\section{REFERENCES}

[1] Seland, E.H. (2011) The Persian Gulf or the Red Sea? Two axes in ancient Indian Ocean trade, where to go and why, World Archaeology, 43(3): 398-409.

[2] Casson, L. (1989) The Priplus Maris Erythraei: Text with Introduction, Translation, and Commentary. Princeton University Press, Princeton, America.

[3] Matthew, A.C. (2018) Exports. In: Rome and the Indian Ocean Trade from Augustus to the Early Third Century CE. Brill, Boston, America.

[4] Mathew, K.S. (2016) Introduction. In: Mathew, K.S. (Ed.), Imperial Rome, Indian Ocean Regions and Muziris. 1st ed. Taylor \& Francis, Oxfordshire, UK.

[5] Seland, E.H. (2013) Networks and Social Cohesion in Ancient Indian Ocean Trade: Geography, Ethnicity, Religion. Journal of Global History, 8 (3): 373-390. 